Ophthalmologica 1949;117:286

\title{
Behandlung der Allergie im aktiven und inaktiven Stadium
} J. Strebel

Luzern

(Erschienen in «Schweiz. Med. Wochenschr.» 1948

Nr. 36

S. 879.) 